\title{
Business terms enrichment by using own flash card
}

\author{
Irmawati $^{* 1}$, Andy Cubalit ${ }^{2}$ \\ ${ }^{*}$ Politeknik Negeri Ujung Pandang, Makassar, Indonesia \\ email: irmawati_pnup09@yahoo.co.id \\ ${ }^{2}$ Walailak University Language Institute, Thailand \\ email: anc457@yahoo.com
}

\begin{abstract}
Vocabulary is the foundation of the language. It is used to communicate for both oral and written communication. Business terms are used to communicate in the business world activities. It may relate to economic, accounting, banking, tourism, hotel, and others business field. This paper focused on the use of flash cards in enriching the students' business terms mastery based on the writers' experience. There are some activities may occur in the classroom by using flashcards. It is classified as memory activity, drilling activity, identification, and Total Physical Response (TPR) activity. They are an abundant approach to present, practice and recycle vocabulary.
\end{abstract}

\section{Keywords:}

Business term; enrichment; flashcard

\section{INTRODUCTION}

English vocabulary is highly essential for the undergraduate students who learn English for Specific Purposes (ESP). Unfortunately, there is no specific subject for teaching and learning vocabulary in a non-English study program at vocational-higher education. Rivers (1981) revealed that it would be incredible to learn a language without vocabulary. For the condition, it needs attention from the teacher or lecturer especially the methods and techniques used in teaching and learning process. The methods used must match with the students' interest, students' level of age or others. By the new method, the students will be fun and enjoy learning with high motivation. Harmer (1983:3) stated that the students are not enthusiastic in memorizing the new words if the method and technique are not attractive. Therefore, it is necessary for the teacher or lecturer of English to provide the matching vocabulary by using some learning aids which can help them to master it, for example, stories, maps, pictures, music, puzzle, brainstorming, matching, flash card, word hunt, and many others techniques.

This paper presents the writers' experience in integrating the vocabulary mastery of the students by playing the game using flash cards at the beginning of each meeting. Using flash card is a delightful way to learn and teach vocabulary. As the writer's experiences in teaching English for non-English students, vocabulary is not becoming a focus topic to be taught. In facing this fact, the lecturers integrate vocabulary in the teaching process as a game for students. One of the games is flashcards. Playing cards with some variation activities are suitable for all ages level as well as at university level. The 
content of the flashcards is related to the business terms, accounting terms for more specific. Mastering business terms will help the students to participate actively in business English class, English for an academic class, English for accounting class, and English for professional class.

\section{LiterATURE REVIEW}

\subsection{Definition of Vocabulary}

Vocabulary is the list of word that has meaning produced by someone or many people to communicate with each other whenever they are, stated by Harmer (1919:51). Carter (1987) states that vocabulary is the word having meaning when heard or seen even though not produced by individual itself to communicate which other. It is the content and function words of a language that are learned so thoroughly, that become a part of child's understanding of four skills.

Vocabulary is the stock of word used by or known to a particular person or group person, list of words or phrases of language (usually arranged in alphabetical orders) stated by Urdan and Flexner (1968:79). While Hornby (1989: 1425) stated some definition of vocabulary; (1) body of words know to a person used in particular book, subject. (2) a total number of words that make up language. (3) list of words that have meaning, especially one that accompanies a textbook in a foreign language.

Webster (1983:2046) stated that vocabulary is (1) a list of the word sometimes a phrase, frequently arranged in sequential order and defined a dictionary, glossary or lexicon. (2) all the words of the language. (3) All the words used by a particular person, class profession, etc and sometimes although not necessarily used by them. Antimoon (2003) divided vocabulary into two parts. They are (1) the vocabulary of a language are all the worlds in that language. (2) a person's vocabulary is all the words that the person knows and understands.

Based on the previous definitions, the writers conclude that the vocabulary is all of the words that have been found or known by a person or more through listening, speaking, reading and writing that have a meaning used to communicate in oral or written.

\subsection{Types of Vocabulary}

Teaching and learning vocabulary is central to the theory and practice of language. It means that the vocabulary classified into two types. They are receptive and productive vocabulary. Receptive vocabulary refers to the words that can be recognized and comprehended in the context of listening and reading. While rich vocabulary refers to the words that we recall and use appropriately in writing and speaking.

Harmer (1991: 159) divides vocabulary into two types, as follows:

a) Active vocabulary refers to vocabulary that has learned by the students and is expected them to be able to use.

b) Passive vocabulary refers to vocabulary that will be recognized by the students when they meet them, but they will probably not be able to produce. 
While Schail (1967) stated that each person has three types of vocabulary, as follows:

a) Active means that these are the words one customarily uses in speaking. The active vocabulary runs from 5.000 to 10.000 words.

b) Back up, these words are known but seldom used in ordinary speech. They usually used for particular writing form, e.g., Academic writing.

c) Passive, the words are recognized vaguely but unsure of the meanings. The words never used at all but it has known or seen previously.

More specific of vocabulary division is pointed out in the encyclopedia of education which divided into four types, as follows:

a) Oral vocabulary consists of words actively used in speech that comes readily to the tongue of the one's conversation.

b) Writing vocabulary is stock of words that come readily to one's finger vocabulary. It commonly used in writing.

c) Listening vocabulary is the words, which a person or more can understand when are hear it.

d) Reading vocabulary is the words someone can recognize when he or she finds it in written material.

\subsection{Selecting Vocabulary}

It is imperative to select vocabulary, the teacher or lecturer must know which words are necessary to learn because many words will not be necessary to teach the students. So the teacher or lecturer chooses the actual word that can be used by the students. Wilkins (1978:113) states that the aim of selecting vocabulary is to retell or make the process of learning most efficient.

To know the kinds of vocabulary being taught, we should consult with a list of words that have been established by the educational department through curriculum or a list of words that used by the particular field of work. We do not only know what words should be presented, but also what is the level of them. To select the business terms means that we have to know what field involves business life. Business is related to Accounting, Economics Marketing, Banking, Insurance, Management, and so forth.

\subsection{The technique of Teaching and Learning Vocabulary}

Nation (1990) said that there are many techniques used in teaching vocabulary and teacher should apply one or more technique in the teaching process. Some criteria of a proper vocabulary teaching technique that should be taken into account, namely:

a) Focus on the words necessary, preferably high-frequency words that have already been met before.

b) Focus on the useful aspect of learning goals.

c) Gets learners to meet or use the word in ways that establish new mental connections for the word.

d) Involves the learners in actively searching for and evaluating the target

Gerlach (1997:188-192) in Adriani (2004:5) stated that there are five types of technology in teaching and learning vocabulary, they are as follows: 
a) Teacher: this technique is probably typical for all techniques. The teacher explanation is the most efficient technique in learning vocabulary.

b) Direct experience: direct experience of the students can motivate them to pour their point of view to communicate.

c) Demonstration: using teaching side and let the students demonstrate a particular thing can motivate them to be seriously in learning.

d) Discussion: of the conference, the technique includes all those activities which develop an interchange of mind between the teacher and the students.

e) Audiovisual materials: this is used to identify all teaching materials available for teacher and students.

f) words in the exercise.

\subsection{The principle of Teaching and Learning Vocabulary}

Wallace (1989) indicates main principles of teaching and learning vocabulary, as follows:

a) Aims: in teaching vocabulary, the teacher must know the aims and how many vocabularies we expect to be able to do? If it is not clear it will be difficult to assess how the vocabulary learning has been attained.

b) Quantity: it is decided on the total of new students can learn words. The actual total will depend on some factors varying in the class and students.

c) Needs: to understand or to select the words that will be taught to the students, these based on frequency and usefulness of the various meaning of a word, students' background and language needs.

d) Frequent Exposure and Repetition: after getting a new vocabulary, it should be repeated continuously or until we remember it well and use it in the proper context as the evidence of mastering the words.

e) Meaningful presentation: in presenting/introducing new words to the students, the teacher explains clearly to sharpen the students' understanding.

f) Situation: in teaching vocabulary, it needs to be known by the teacher and study the situation of the whole class whether the students are ready to accept the materials or not.

g) Presenting: one way to present new words or unfamiliar words is by using reading text.

h) Learning vocabulary in mother tongue and target language: in teaching the words of the target language, the teacher can use words of the mother tongue as a tool to compare similarities and differentiate of the words.

i) The inference is also a strategy in learning vocabulary that the learners are hard in practice by using definite knowledge to have sharpened understanding the words that they learn. The students infer the meaning of words by listening or reading them used in particular context and specific situation.

Similarly, Olha Madylus states four principles for teaching and learning vocabulary, they are: 
a. Recycling. It is vital to ensure that new vocabulary is regularly recycled/revised because if students do not get the chance to put it to use, they will quickly forget it.

b. Motivation. It is also essential to ensure teenagers are paying attention and involved in their lessons and lots of ideas for practicing vocabulary.

c. Exams. An aspect of language that is judged in examinations is the range of vocabulary that students have, so they must be able to use vocabulary they have learned effectively in exam situations.

d. Communication. In order to communicate clearly and effectively a good range of vocabulary is needed, it enriches both spoken and written language.

\subsection{Flashcard}

Flashcard enables students to master the vocabulary faster than other methods. As stated by Hall, flashcards are not only as a memory tool; it is also can be used to solve the problem and mind processing for every case. Flashcard is a unique art and science, the text on a flash card on both sides. Flashcards are a simple, versatile, yet often under-exploited resource.

Flashcards are a valuable resource for teachers and parents. They are used as a linguistic or visual stimulus for learners to read, speak or write. In Webster dictionary, flashcard is a card contains words, numbers, or pictures that are used to make the students quickly learn a word comprehensively. Similarly, in dictionary.com stated that flashcard is a card with a specific word, numerals, or photograph on it. It is designed to attract the fast response of the students when learning vocabulary. From the previous definitions, it is concluded that flash card is a small paper in size with text, picture, or sentence on it to be used as a tool guide for speaking, writing, listening, or reading.

\section{DISCUSSION}

Based on the writer's experiences in using flashcards, there are some activities may occur in the classroom by using flashcards. It is classified as memory activity, drilling activity, identification, and Total Physical Response (TPR) activity. It describes in the following parts:

\subsection{Memory Activity}

In this stage, the teacher or lecturer places the cards in the middle of the class. The students are standing around the cards and memorize the visible words for particular time. After that, the students are given the time to rewrite the words they remember as much as possible. After rewriting their words, they share the words through Facebook group chat, so that the other students can see all of their words. The students are also able to memorize some words as the result of their game in the small group as illustrated in the following parts.

\subsection{Drilling Activity}

Form the students in a small group of four and sit in a cycle. The cards are distributed equally to the students. In turn, the student shows the card one by one and the student who sits in clockwise guess the meaning of the word. It is repeated until the cards are out of hand. This activity sometimes followed by 
the presentation. The students choose one of the words they know well and then present it entirely like the definition of the words, how to record it in the financial report, etc. The cards are also can be used as a tool for the spelling bee. The lecturer can give two ways of spelling; mention the word and the students spell it, or the lecturer spells the word, and the students guess it. Do not forget the further activity of spelling bee is find the meaning of the word, the synonym, or antonym.

\subsection{Identification}

The lecturers flip the card fastly, so the students get a quick glimpse. This is repeated until the students can guess the words flip. This is the keeping focus and concentration game. Another activity in playing the cards by identification stage is placed as much as possible flashcards on the floor; then the lecturer mentions the English or Bahasa of the words behind the visible word and the students will race take the cards if they know the meaning of the words. This is a similar game of "show me" game.

\subsection{Total Physical Response (TPR)}

The cards are stuck around the class; the lecturer says one of the words and the student's race to get it. The students who get the card can then instruct the classmates. The students who get the cards most widely become the winner of the game. Sometimes, I directly take the cards one by one and show them to the students and the student's race to guess the meaning of the words.

\section{Conclusion}

Using the flash card in improving vocabulary mastery can be used by all age level of students. The students create their flashcards accordingly. Using flash cards can help the students in mastering vocabulary that can bring them to do more on language skills. Flash cards can be bright and exciting and make a real impact on visual learners. It is quite violent for the students to memorize new business terms only by looking at the text. With flashcards, they may play with it variously to attract their memory.

Flashcards are an indeed useful resource to have and can be worthwhile at each stage of the class. They are an excessive approach to offer, practice and repeat the vocabulary. When the students are familiar with the class activities in using the flashcards, they can play by themselves. If I could not be with them in any longer time at the class, I ask them to play in a small group as they always do earlier of the meeting.

\section{REFERENCES}

Adriani. (2004). Teaching English Vocabulary Using Pictures to the Students of SLTPN 1 Jeneponto. Unpublished. Thesis.

Antimoon, Team. (2003). Definition of English Words Vocabulary. http://www.Antimoon.com/words/Vocabulary-n-htm.

Carter, R. (1987). Vocabulary: Applied linguistic perspectives. London: Allen and Unwin.

Hall, David A. MD www.freeworldu.org/static/flashcardtheory.aspx. version; 2.1d

Harmer, Jeremy. (1991). The Practice of English Language Teaching. Longman. Handbooks for Language Teacher. London \& New York. 
Hornby, A.S. (2000). Oxford Advance of Learner's dictionary of Current English. Sixth Edition. Express University Press.

http://dictionary.reference.com/browse/flashcard.

http://www.teachingenglish.org.uk/article/using-flash-cards-young-learners

http://www.merriam-webster.com/dictionary/flash\%20cardhttp://www.asian-EFLjournal.com/sept_05_pn.pdf

http://www.aminlimpo.com/2012/05/concept-of-vocabulary.html.

Nation, I. S. P. (1990).Teaching and learning vocabulary. Boston, Mass.: Heinle\&Heinle Publishers.

Rivers, W. M. (1981). Teaching Foreign Language Skills. Chicago: The University of Chicago Press.

Schail, W.S. (1967). Seven Days for Faster Reading. Paperback. New York.

Urdan, Laurence, and Flexner, Stuart. (1968). The Random House of the dictionary. House, Inc. New York.

Wallace, Michael J. (1989). Teaching Vocabulary ELBS. Oxford University Press Inc. New York.

Webster. (1983). Webster's Encyclopedic Dictionary of the English Language. Portland House. A Division of Dilithium Press Ltd.

Wilkinson, Gene L. (1978). Media dalam Pembelajaran: Penelitian Selama 60 Tahun. Edisi Indonesia: CV. Rajawali. 